\title{
Summer microplankton community structure across the Scotia Sea: implications for biological carbon export
}

\author{
R. E. Korb ${ }^{1}$, M. J. Whitehouse ${ }^{1}$, M. Gordon ${ }^{1}$, P. Ward ${ }^{1}$, and A. J. Poulton ${ }^{2}$ \\ ${ }^{1}$ British Antarctic Survey, Natural Environmental Research Council, High Cross, Madingley Road, Cambridge CB3 0ET, UK \\ ${ }^{2}$ National Oceanography Centre, Southampton, University of Southampton, Waterfront Campus, SO14 3ZH, UK
}

Received: 23 September 2009 - Published in Biogeosciences Discuss.: 13 October 2009

Revised: 5 January 2010 - Accepted: 7 January 2010 - Published: 28 January 2010

\begin{abstract}
During the austral summer of 2008, we carried out a high resolution survey of the microplankton communities along a south to north transect covering a range of environments across the Scotia Sea, Southern Ocean; high and low productivity, sea-ice to open water conditions, and over a number of oceanographic fronts and bathymetric features. Cluster analysis revealed five distinct communities that were geographically constrained by physical features of bathymetry and fronts. From south to north the communities were: (1) the South Orkney group, a mixed community of naked dinoflagellates and heavily silicified diatoms, (2) southern Scotia Sea, a mixed community of cyptophytes and naked dinoflagellates, (3) central Scotia Sea, dominated by naked dinoflagellates, (4) southwest of the island of South Georgia, lightly silicified diatoms and naked dinoflagellates (5) northwest of South Georgia, dominated by diatoms. Data from a previous summer cruise (2003) to the Scotia Sea followed a similar pattern of community distribution. MODIS images, Chlorophyll $a$ and macronutrient deficits revealed dense phytoplankton blooms occurred around the island of South Georgia, were absent near the ice edge and in the central Scotia Sea and were moderate in the southern Scotia Sea. Using these environmental factors, together with community composition, we propose that south of the Southern Antarctic Circumpolar Current Front, biogenic silica is preferentially exported and north of the front, in the vicinity of South Georgia, carbon is exported to depth.
\end{abstract}

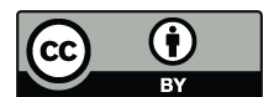

Correspondence to: R. E. Korb (bxkorb@googlemail.com)

\section{Introduction}

The Scotia Sea, in the south Atlantic sector of the Southern Ocean, is a region of complex bathymetry with numerous seamounts and oceanic islands. Satellite, ocean colour images have shown these topographic features support extensive blooms which stand in stark contrast to the high-nutrient, low chlorophyll (HNLC) conditions characterising much of the open Southern Ocean (Comiso et al., 1993; Arrigo et al., 1998; Holm-Hansen et al., 2004a; Korb et al., 2004; Tyrrell et al., 2005). Similar to phytoplankton blooms in the vicinity of the Kerguelen Islands (Blain et al., 2007) and Crozet Islands (Pollard et al., 2007), blooms associated with the Scotia Sea islands are the result of both macro- and micronutrient enrichment in surface waters over a stable water column (Holm-Hansen et al., 2004b; Korb et al., 2008).

Highly productive islands within the open ocean are likely to represent "hotspots" of carbon export compared to typical HNLC Antarctic waters. In particular, the large and intense blooms of the northern Scotia Ridge (Scotia Sea) are associated with the strongest predicted carbon sink in the Southern Ocean (Schlitzer, 2002). There is currently much debate on the possibility of stimulating phytoplankton blooms to remove carbon from surface waters to the deep (e.g. see Theme Section on Iron fertilization in MEPS, introduced by Boyd, 2008). However, the processes of carbon removal are complex and diverse. Indeed, a consensus is yet to be reached on exactly how much carbon is exported from both artificially induced and, naturally occurring blooms (de Baar et al., 2005; Boyd et al., 2007; Pollard et al., 2009). Many factors will affect the export of carbon to depth but one of the major influences is certainly the structure of the pelagic food web, in particular the contribution of diatoms (Boyd and Newton, 1999). As aggregates, dense blooms of large

Published by Copernicus Publications on behalf of the European Geosciences Union. 
diatoms may rapidly sink out of the euphotic zone (De La Rocha and Passow, 2007). As a major component of krill diets, diatoms will be packaged into faecal pellets, another major vector for the sinking of carbon to the deep sea (De La Rocha and Passow, 2007).

Throughout the open Southern Ocean, island phytoplankton blooms are generally dominated by either diatoms or by the prymnesiophyte Phaeocystis antarctica (Armand et al., 2008; Korb et al., 2008; Poulton et al., 2007). Blooms at South Georgia, on the northern Scotia Ridge, are generally dominated by diatoms but can also contain significant numbers of heterotrophic dinoflagellates (Korb et al., 2008; Korb and Whitehouse, 2004). Such a food web could have important implications for carbon export in this region with diatoms as potential carbon sinks vs carbon recycling by heterotrophic dinoflagellates (Archer et al., 1996; Smetacek et al., 2004).

In this study we undertook a detailed examination of microplankton $(>10 \mu \mathrm{m})$ community composition across the Scotia Sea. A transect ran from the ice edge in the south to the South Georgia bloom in the north, crossing a number of water bodies, each with unique physical and chemical properties. Here we relate the patterns of community composition to environmental conditions and discuss our results in terms of potential carbon export during the austral summer.

\section{Methods}

\subsection{Cruise details}

Our main data set was collected in January-February 2008 (cruise number JR177) aboard the "RRS James Clark Ross". Our survey followed a transect line which began in brash ice to the south, ran to the east of Signy Island and then followed a European Remote Sensing satellite altimeter track to the northwest of South Georgia (Fig. 1). CTD stations occupied along the transect line were part of the British Antarctic Survey's, Dipycnal and Isopycnal Mixing Experiment in the Scotia Sea (DIMES) project and are named according to their DIMES location starting with the most southerly station D1, up to the most northerly station, D34. For comparison, we also present data from an earlier, wider scale, Scotia Sea survey (cruise JR82, January 2003; Korb et al., 2005). Here we only included stations in close proximity $(<150 \mathrm{~km})$ to the 2008 transect line. Station numbering follows that of the original 2003 survey.

\subsection{Sampling and physical measurements}

At stations, vertical profiles of temperature, salinity and depth were measured using a SeaBird 911+CTD. A SeaBird 12-position carousel water sampler with 101 Niskin bottles was used to collect discrete water samples from the upcast of the CTD. This water was used to measure Chlorophyll $a(\mathrm{Chl} a)$, macronutrients and assess phytoplankton

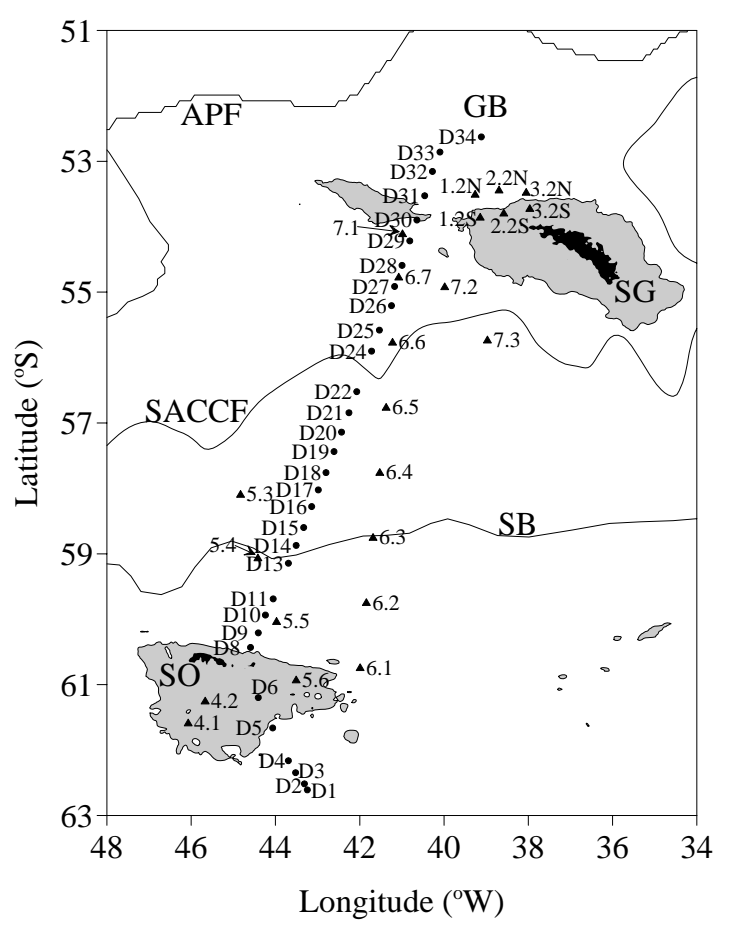

Fig. 1. Station locations of the 2008 (circles) and 2003 (triangles) Scotia Sea surveys. Grey shading indicates the $2000 \mathrm{~m}$ isobaths. Mean frontal positions are indicated by; APF - Antarctic Polar Front, SACCF - Southern Antarctic Circumpolar Current Front and SB - Southern Boundary. GB - Georgia Basin, SG - South Georgia, SO - South Orkney Islands.

community composition. An Aqua-Tracka Mk III fluorometer (Chelsea Instruments) and a PAR sensor (Biospherical Instruments Inc.) were mounted on the CTD frame. All sensor data from the downcast of the CTD were averaged onto 2 dbar pressure levels for analysis.

The depth of the euphotic zone ( $Z e$ ) was defined as that of the $1 \%$ incident light level and was calculated by estimating the scalar attenuation coefficient $(K d)$ of the water column from the linear regression of the log transformed irradiance (PAR) vs. depth profile of the CTD's (Kirk, 1994). In the absence of light profiles at night-time stations, euphotic depth was estimated from relationships between euphotic depth and $\mathrm{Chl} a$ concentration and was calculated separately for each cruise.

The upper mixed layer (UML) depth was defined as a well mixed layer that reached the surface and contained no vertical density gradients $>0.01 \mathrm{~kg} \mathrm{~m}^{-3} 10 \mathrm{~m}^{-1}$.

A Winter Water (WW) layer was clearly discernable in vertical potential temperature profiles (Jennings et al., 1984; Meredith et al., 2005). It was identified as a distinct depth band containing $\theta_{\min }$ (the potential temperature minimum) water and was located on average at $104 \mathrm{~m}$ (range 61 to $142 \mathrm{~m}$ ) during the present study. The shallowest limit of this band represents the depth to which current summer warming 
has penetrated and nutrient concentrations at this depth are indicative of surface conditions during the previous winter, when deep mixing and re-supply to the surface had occurred.

\subsection{Cell counts and biomass estimates}

Water samples were taken from the $20 \mathrm{~m}$ CTD bottle for cell counts and biomass estimates, and were preserved with 1$2 \%$ acidic Lugols' solution in $250 \mathrm{ml}$ brown glass bottles. Cell enumeration followed Hasle (1978), with $50 \mathrm{ml}$ subsamples settled for 20-24 h in Hydro-Bios (Duncan \& Associates, UK) chambers, and examined using a SP-95-I inverted microscope (Brunel Microscopes Ltd, UK). Plankton were counted from full examination of the settling chamber (x200), apart from when taxa were present in high numbers and were counted from 1-2 transects of the settling chamber (x100 or x200). For the 2008 cruise, diatoms and dinoflagellates were identified to genera or species following Priddle and Fryxell (1985), Tomas (1997) and Scott and Marchant (2005), with unidentified taxa (e.g. planktonic ciliates) grouped according to cell size. On the 2003 cruise, taxonomic resolution was coarse, with only large, dominant cells counted $(>10 \mu \mathrm{m})$, and no attempt to enumerate small cells. Cell biomass (pg C cell ${ }^{-1}$ ) for all taxa were estimated from cell measurements following Poulton et al. (2007), and are in good agreement with similar studies in the Southern Ocean (Schultes et al., 2006; Armand et al. 2008). We use the biomass size classes stated in Armand et al. (2008) to determine a species' overall contribution to biomass as being large $\left(>488 \mathrm{pg} \mathrm{C}\right.$ cell $\left.^{-1}\right)$, medium $\left(85-488 \mathrm{pg} \mathrm{C}\right.$ cell $\left.^{-1}\right)$ or small $\left(<85 \mathrm{pg} \mathrm{C}\right.$ cell $\left.^{-1}\right)$.

\subsection{Chlorophyll $a$ estimates}

Chl $a$ was measured using standard methods as detailed in Korb and Whitehouse (2004). Individual fluorescence profiles from the Aqua Tracka were calibrated (linear regression) against extracted Chl $a$ to determine relative distributions of phytoplankton biomass. As high PAR can inhibit fluorescence, we examined PAR profiles and only regressed fluorescence against Chl $a$ where PAR was $\leq 40 \mu \mathrm{mol} \mathrm{m}{ }^{-2} \mathrm{~s}^{-1}$ (adopted from methods of Holm-Hansen et al., 2000). The relationship between fluorescence and extracted Chl $a$ was good with mean $r^{2}$ for all stations $\sim 0.85$. Linear regression equations were then applied to the high resolution fluorescence profile where PAR $\leq 40 . \mu \mathrm{mol} \mathrm{m} \mathrm{m}^{-2} \mathrm{~s}^{-1}$. Calibrated fluorescence values at $\sim 40 \mu \mathrm{mol} \mathrm{m}{ }^{-2} \mathrm{~s}^{-1}$ were used to represent the upper portion of the fluorescence profile where PAR was higher than $40 \mu \mathrm{mol} \mathrm{m} \mathrm{m}^{-2} \mathrm{~s}^{-1}$.

Monthly, Level 3, surface Chl $a$ data from the MODISAqua satellite were obtained from NASA's Ocean Colour website (http://oceancolor.gsfc.nasa.gov/).

\subsection{Macronutrient analysis}

Samples for nutrient analysis were filtered through a mixed ester membrane (pore size $0.45 \mu \mathrm{m}$, Whatman), and the filtrate was analysed colorimetrically for dissolved silicate $\left(\mathrm{Si}[\mathrm{OH}]_{4}-\mathrm{Si}\right)$, phosphate $\left(\mathrm{PO}_{4}-\mathrm{P}\right)$, nitrate $\left(\mathrm{NO}_{3}-\mathrm{N}\right)$ and ammonium $\left(\mathrm{NH}_{4}-\mathrm{N}\right)$ with a segmented-flow analyser (Technicon, Whitehouse, 1997). The nitrate measurement included nitrite $\left(\mathrm{NO}_{2}\right)$, which is not considered separately as its concentration varied little and typically comprised $<1 \%$ of total $\mathrm{NO}_{3}+\mathrm{NO}_{2}$.

To enable regional comparisons to be made, nutrient deficits and paired deficit ratios for each station were estimated from the difference between concentrations in the winter water (WW) layer and those in the surface waters (0$25 \mathrm{~m}$ ) above it (Jennings et al., 1984). This simple method presumes minimal lateral mixing, vertical diffusion, and remineralisation, but has been found previously to be reasonably robust (Rubin et al., 1998; Whitehouse et al., 2008). Furthermore, it has the advantage of using the same profile to estimate pre- and bloom concentrations within a narrow spatial and temporal window. As our sampling was undertaken just weeks after the bloom initiation, and our stations were not straddling fronts (Fig. 1 illustrates mean positions), we consider this an acceptable method of estimating an index of nutrient use.

\subsection{Data analysis}

Phytoplankton cell counts from both cruises were analysed with the statistical package PRIMER 6 (Primer-E Ltd). Cell counts were standardised and then square root transformed and subjected to $q$ type cluster analysis based on the BrayCurtis similarity and group average linkage classification (Field et al., 1982).

Significant differences between regional station groups were tested using a 1-way ANOVA followed by Tukey's multiple comparison tests.

\section{Results}

\subsection{Phytoplankton communities and cell abundance across the Scotia Sea}

\subsubsection{Summer 2008}

Cluster analysis showed that our stations could be divided into five major clusters based on similarity in phytoplankton species abundance at the $60 \%$ Bray-Curtis similarity level (Fig. 2a and b). Most of the stations within groups were located close together and were largely constrained by physical features of bathymetry and fronts. Therefore we named the clusters according to geographical location as follows:

- ORK group - stations largely running south-eastwards, from the South Orkneys shelf to the ice edge. However, 

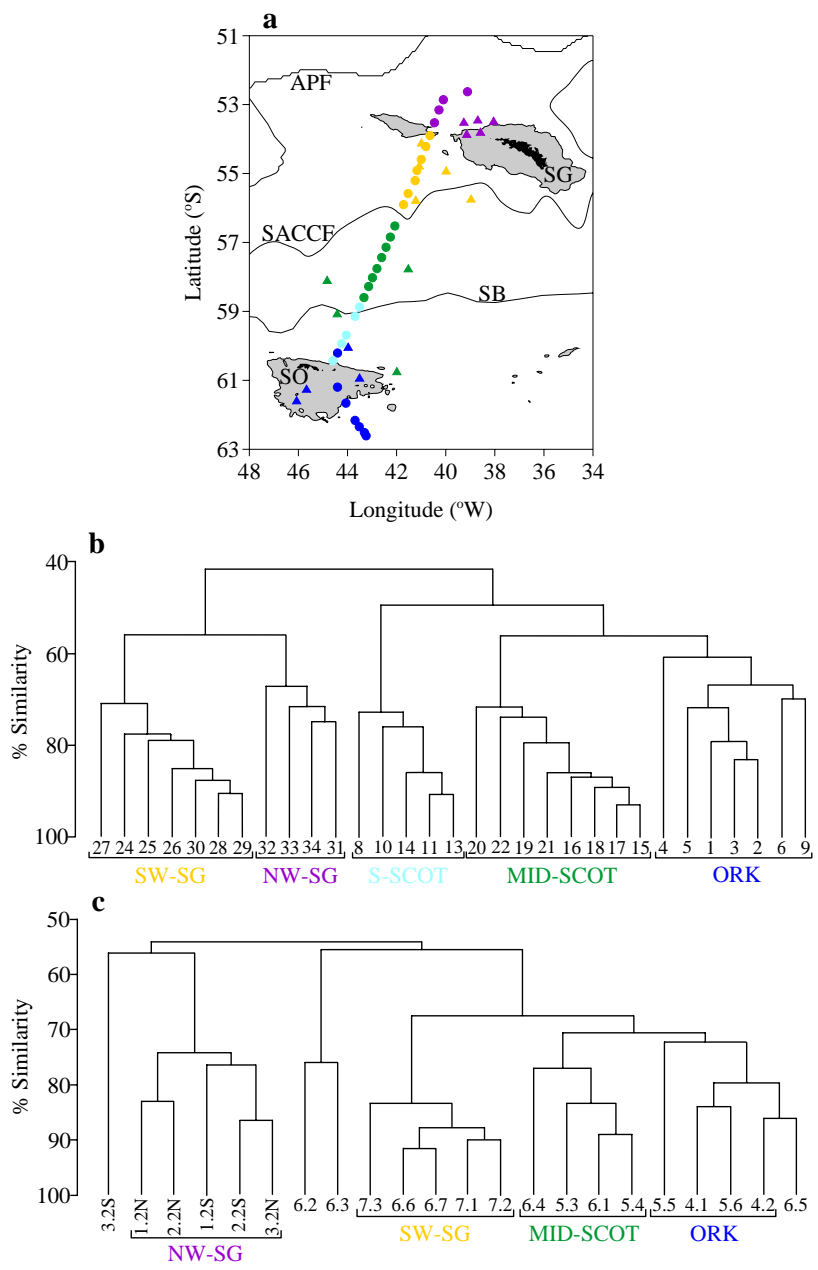

Fig. 2. (a) Location of the 2008 (circles) and 2003 (triangles) regional station groups from cluster analysis. (b) Cluster diagram of phytoplankton abundance for 2008 and (c) 2003. Black bars indicate distinct station groups at the $60 \%$ (b) and $72 \%$ (c) Bray-Curtis similarity level. Station groups from south to north are: ORK South Orkney, S-SCOT - southern Scotia Sea, MID-SCOT - central Scotia Sea, SW-SG - southwest of South Georgia, NW-SG northwest of South Georgia.

station D9 was located slightly north of the shelf. This group was composed of a mixed community of diatoms and dinoflagellates (37\% and $62 \%$ of the total cell count; Fig. 3a). The dinoflagellates in this group, and indeed throughout the entire survey, were made up exclusively of small to medium sized ( $\leq 40 \mathrm{um}$ ), naked dinoflagellates. The diatom component was dominated by Fragilariopsis spp. (6-35\% of total cell count; Table 1).

- S-SCOT - stations situated in the southern Scotia Sea, north of the S. Orkneys shelf and along, or to the south of, the Southern Boundary Front (SB). This group contained mainly cryptophytes and naked dinoflagellates (53 and $44 \%$ of the total; Fig. 3a, Table 1).

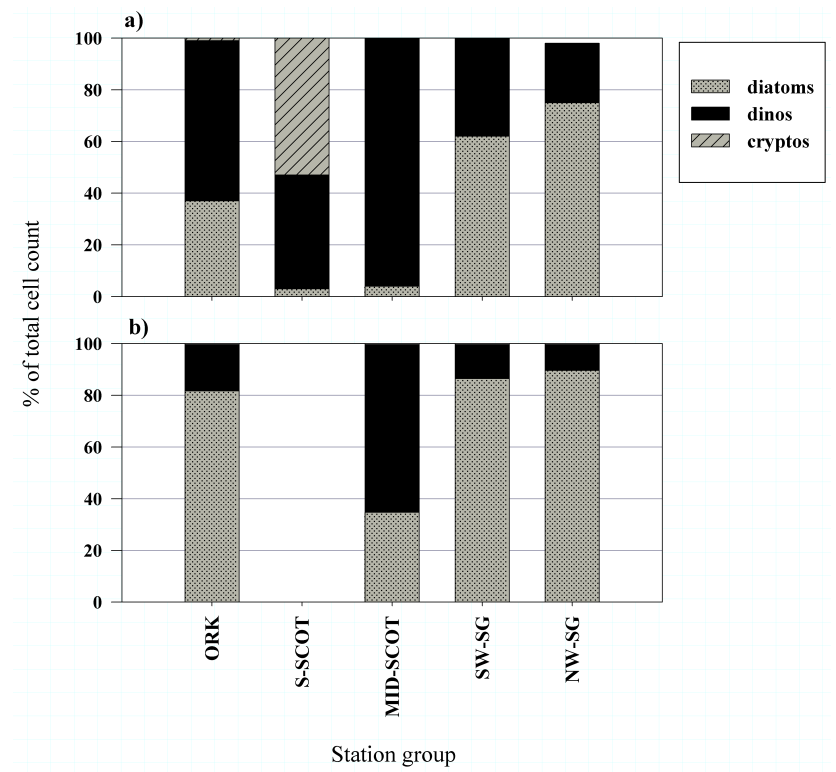

Fig. 3. Microplankton community composition (cell abundance) of the station groups for the (a) 2008 and (b) 2003 cruises. Dinos dinoflagellates, Cryptos - cryptophytes.

- MID-SCOT - stations situated in the central Scotia Sea, north of the SB and along, or to the south of, the Southern Antarctic Circumpolar Current Front (SACCF). Naked dinoflagellates dominated this group with $96 \%$ of the total cell count.

- SW-SG - stations north of the SACCF and to the south west of the island of South Georgia. Diatoms became more abundant in this group making up $62 \%$ of the total count. However, naked dinoflagellates still contributed significantly to the overall community ( $38 \%$ of the total).

- NW-SG - stations situated to the north-west of South Georgia. Diatoms accounted for the majority of the cell abundances $(75 \%)$ and a smaller contribution was seen from naked dinoflagellates (23\%). Silicoflagellates also appeared in this group although their overall contribution to cell abundances was small (2\%).

Mean cell concentrations were greatest in the S-SCOT and SG groups (203-354 cells ml ${ }^{-1}$; Table 1) and lowest in the MID-SCOT and ORK groups, 56 and 94 cells ml ${ }^{-1}$, respectively.

\subsubsection{Summer 2003}

During the 2003 cruise, stations could be divided into 2 major clusters based on similarity in phytoplankton community abundance (at the $60 \%$ Bray-Curtis similarity level, see Fig. 2a and c). Most of the stations south of South Georgia fell into 1 group with the exception of stations 6.2 and 6.3 
Table 1. Community composition of the 2008 summer stations (cell abundance), N.D. indicates no dominant species.

\begin{tabular}{|c|c|c|c|c|c|c|}
\hline \multirow[b]{2}{*}{ Stn } & \multirow[b]{2}{*}{ Group } & \multirow{2}{*}{$\begin{array}{c}\text { Total cell } \\
\text { abundance } \\
\left(\text { cells ml }{ }^{-1}\right)\end{array}$} & \multicolumn{3}{|c|}{$\begin{array}{l}\text { Dominant phytoplankton } \\
\text { (as \% of total cell count) }\end{array}$} & \multirow[t]{2}{*}{$\begin{array}{l}\text { Dominant diatom } \\
\text { (\% of total cell count) }\end{array}$} \\
\hline & & & Diatoms & Dinoflagellates & Cryptophytes & \\
\hline 1 & ORK & 57.48 & 27 & 73 & 0 & Fragilariopsis spp. (18) \\
\hline 2 & ORK & 19.52 & 31 & 68 & 0 & Fragilariopsis spp. (14) \\
\hline 3 & ORK & 36.08 & 38 & 62 & 0 & Fragilariopsis spp. (23) \\
\hline 4 & ORK & 294.84 & 75 & 25 & 0 & Fragilariopsis spp. (35) \\
\hline 5 & ORK & 111.64 & 46 & 54 & 0 & Fragilariopsis spp. (22) \\
\hline 6 & ORK & 45.92 & 21 & 74 & 5 & Fragilariopsis spp. (6) \\
\hline \multirow[t]{2}{*}{9} & ORK & 92.68 & 16 & 81 & 3 & Fragilariopsis spp. (13) \\
\hline & Avg & 94 & 37 & 62 & 1 & \\
\hline 8 & S-SCOT & 353.24 & 12 & 46 & 42 & Fragilariopsis spp. (7) \\
\hline 10 & S-SCOT & 230.92 & 1 & 24 & 75 & N.D. \\
\hline 11 & S-SCOT & 171.8 & 1 & 53 & 46 & N.D. \\
\hline 13 & S-SCOT & 198.16 & 1 & 40 & 59 & N.D. \\
\hline \multirow[t]{2}{*}{14} & S-SCOT & 171.4 & 1 & 55 & 45 & N.D. \\
\hline & $A v g$ & 225 & 3 & 44 & 53 & \\
\hline 15 & MID-SCOT & 89.8 & 1 & 99 & 0 & N.D. \\
\hline 16 & MID-SCOT & 85.68 & 3 & 97 & 0 & N.D. \\
\hline 17 & MID-SCOT & 91.96 & 2 & 98 & 0 & N.D. \\
\hline 18 & MID-SCOT & 42.92 & 2 & 98 & 0 & N.D. \\
\hline 19 & MID-SCOT & 23.84 & 5 & 94 & 0 & N.D. \\
\hline 20 & MID-SCOT & 26.76 & 7 & 92 & 0 & N.D. \\
\hline 21 & MID-SCOT & 44.4 & 2 & 97 & 0 & N.D. \\
\hline \multirow[t]{2}{*}{22} & MID-SCOT & 41.48 & 7 & 92 & 0 & N.D. \\
\hline & Avg & 56 & 4 & 96 & 0 & \\
\hline 24 & SW-SG & 184.44 & 49 & 51 & 0 & P. lineola (26) \\
\hline 25 & SW-SG & 510.12 & 88 & 11 & 0 & P. lineola (46) \\
\hline 26 & SW-SG & 410.26 & 74 & 26 & 0 & P. lineola $(30)$ \\
\hline 27 & SW-SG & 154.52 & 52 & 47 & 0 & Chaetoceros spp. (24) \\
\hline 28 & SW-SG & 321.92 & 55 & 44 & 0 & P. lineola $(21)$ \\
\hline 29 & SW-SG & 355.52 & 54 & 46 & 0 & P. lineola (23) \\
\hline \multirow[t]{2}{*}{30} & SW-SG & 343.24 & 60 & 39 & 0 & P. lineola (14) \\
\hline & Avg & 326 & 62 & 38 & 0 & \\
\hline 31 & NW-SG & 558.44 & 78 & 22 & 0 & M. adele (47) \\
\hline 32 & NW-SG & 435.68 & 79 & 20 & 0 & M. adele (65) \\
\hline 33 & NW-SG & 150.44 & 68 & 32 & 0 & M. adele (32) \\
\hline \multirow[t]{2}{*}{34} & NW-SG & 272.4 & 77 & 19 & 0 & M. adele (24) \\
\hline & $A v g$ & 354 & 75 & 23 & 0 & \\
\hline
\end{tabular}

which formed their own group. The other major cluster comprised stations to the north of South Georgia, although station $3.2 \mathrm{~S}$ was an outlier to the cluster. We note that cell counts from 2003 were much coarser than from our 2008 survey (see methods). Therefore, we looked at the cluster analysis at a higher level, $\sim 72 \%$, and found 4 main clusters that broadly corresponded to the 2008 cruise. Thus we defined 4 main regional groupings, in a manner similar to 2008 groups, as follows:
- ORK - this cluster group mainly consisted of stations close to the Orkney shelf but also included station 6.5. As this station was geographically remote from the other stations in the cluster, it was not included in this grouping. Generally the ORK group was dominated by diatoms but held a moderate proportion of dinoflagellates as well ( 82 and $18 \%$ of total cell count; Fig. 3b). The diatom component was comprised largely of Thalassionema spp. (51-74\% of total count; Table 2). 
Table 2. Community composition of the 2003 summer stations (cell abundance). Thal/Frag - Thalassionema/Fragilariopsis spp., Nitzs/Pseudonitzsspp. - Nitzschia/Pseudonitzschia spp.

\begin{tabular}{|c|c|c|c|c|c|}
\hline \multirow[b]{2}{*}{ Stn } & \multirow[b]{2}{*}{ Group } & \multirow{2}{*}{$\begin{array}{c}\text { Total cell } \\
\text { abundance } \\
\left(\text { cells } \mathrm{ml}^{-1}\right)\end{array}$} & \multicolumn{2}{|c|}{$\begin{array}{l}\text { Dominant phytoplankton } \\
\text { (\% of total count })\end{array}$} & \multirow[t]{2}{*}{$\begin{array}{l}\text { Dominant diatom } \\
\text { (\% of total count })\end{array}$} \\
\hline & & & Diatoms & Dinoflagellates & \\
\hline 4.1 & ORK & 157.96 & 93 & 7 & Thal/ Frag spp. (74) \\
\hline 4.2 & ORK & 179.39 & 90 & 10 & Thal/ Frag spp. (51) \\
\hline 5.5 & ORK & 37.35 & 56 & 44 & Thal/ Frag spp. (41) \\
\hline \multirow[t]{2}{*}{5.6} & ORK & 42.65 & 88 & 12 & Thal/ Frag spp. (67) \\
\hline & Avg & 104 & 82 & 18 & \\
\hline 5.3 & MID-SCOT & 31.84 & 31 & 69 & F. kerguelensis (22) \\
\hline 5.4 & MID-SCOT & 33.06 & 46 & 54 & F. kerguelensis (6) \\
\hline 6.1 & MID-SCOT & 23.67 & 50 & 50 & F. kerguelensis (20) \\
\hline \multirow[t]{2}{*}{6.4} & MID-SCOT & 30.82 & 62 & 38 & F. kerguelensis (17) \\
\hline & $A v g$ & 30 & 47 & 53 & \\
\hline 6.6 & SW-SG & 367.76 & 90 & 10 & Chaetoceros spp.(41) \\
\hline 6.7 & SW-SG & 437.55 & 89 & 11 & Chaetoceros spp.(37) \\
\hline 7.1 & SW-SG & 480.82 & 88 & 12 & Chaetoceros spp. (39) \\
\hline 7.2 & SW-SG & 613.06 & 91 & 9 & Chaetoceros spp. (51) \\
\hline \multirow[t]{2}{*}{7.3} & SW-SG & 95.71 & 75 & 25 & Nitzs /Pseudonitzs spp. (32) \\
\hline & Avg & 399 & 87 & 13 & \\
\hline $\mathrm{W} 1.2 \mathrm{~S}$ & NW-SG & 694.90 & 95 & 5 & E. antarctica $(82)$ \\
\hline $\mathrm{W} 2.2 \mathrm{~S}$ & NW-SG & 397.35 & 84 & 16 & E. antarctica $(56)$ \\
\hline $\mathrm{W} 1.2 \mathrm{~N}$ & NW-SG & 723.67 & 92 & 8 & E. antarctica (73) \\
\hline $\mathrm{W} 2.2 \mathrm{~N}$ & NW-SG & 380.61 & 84 & 16 & E. antarctica (40) \\
\hline \multirow[t]{2}{*}{$\mathrm{W} 3.2 \mathrm{~N}$} & NW-SG & 668.16 & 93 & 7 & E. antarctica (69) \\
\hline & $A v g$ & 573 & 90 & 10 & \\
\hline
\end{tabular}

- MID-SCOT - this group was located largely within the MID-SCOT region of the 2008 survey, although we note that station 6.1 was located further south, near the South Orkney shelf. The 2003 group consisted of a mixed community of naked dinoflagellates and diatoms (53 and $47 \%$ of total; Fig. 3b). Fragilariopsis kerguelensis was the most abundant diatom (Table 2).

- SW-SG - dominated by diatoms (87\% of total), in particular Chaetoceros spp.

- NW-SG - dominated by diatoms (90\% of total), mainly Eucampia antarctica.

Mean cell concentrations were greatest in the SG groups (399-573 cells ml ${ }^{-1}$; Table 2), intermediate in the ORK group $\left(104\right.$ cells ml $\left.{ }^{-1}\right)$ and lowest in the MID-SCOT (30 cells ml ${ }^{-1}$ ).

\subsection{Carbon biomass of phytoplankton communities across the Scotia Sea - summer 2008}

Mean biomass ranged from 12 and $18 \mathrm{mg} \mathrm{m}^{-3}$ at the S-SCOT and MID-SCOT groups, respectively, up to 61-
$70 \mathrm{mg} \mathrm{C} \mathrm{m}^{-3}$ in the ORK, SW-SG and NW-SG groups (Table 3 ).

In the S-SCOT and MID-SCOT groups, where diatoms were numerically low, dinoflagellates and cryptophytes contributed the most to cell biomass (Fig. 4). However, diatoms contributed a third of total cell biomass in these groups (25-35\%). The large sized diatom, Corethron pennatum (8628 $\mathrm{pg} \mathrm{C}$ cell $^{-1}$ ), contributed substantially (up to $70 \%$ ) to total biomass at almost all stations. Biomass in the ORK group, where diatoms made up a third of cell counts, was also largely dominated by $C$. pennatum or the medium sized Fragilariopsis kerguelensis (164 pg C cell-1).

In contrast, cell biomass of the numerically "diatom rich" groups was made up of smaller diatoms. The medium sized, Pseudonitzschia sp. (220 pg Ceell $\left.{ }^{-1}\right)$, dominated biomass (23-40\% of the total) in the SW-SG group and the NWSG group was dominated by Thalassiothrix antarctica (1321 pg Ceell $\left.{ }^{-1}\right)$.

\subsection{Oceanographic parameters across the Scotia Sea}

During both the 2003 and 2008 austral summers, MODIS images showed blooms occurred downstream of the island of 
Table 3. Carbon biomass of the 2008 summer stations.

\begin{tabular}{|c|c|c|c|c|c|c|}
\hline \multirow[b]{2}{*}{ Stn } & \multirow[b]{2}{*}{ Group } & \multirow{2}{*}{$\begin{array}{c}\text { Total cell } \\
\text { biomass } \\
\left(\mathrm{mg} \mathrm{C} \mathrm{m}^{-3}\right)\end{array}$} & \multirow[b]{2}{*}{ Diatoms } & \multicolumn{2}{|c|}{$\begin{array}{l}\text { Carbon cell biomass } \\
\text { (as \% of total) }\end{array}$} & \multirow[t]{2}{*}{$\begin{array}{l}\text { Dominant diatom } \\
\text { (\% of total carbon biomass) }\end{array}$} \\
\hline & & & & Dino-flagellatess & Crypto-phytes & \\
\hline 1 & ORK & 8.34 & 52 & 48 & 0 & Fragilariopsis spp. (20) \\
\hline 2 & ORK & 3.08 & 60 & 40 & 0 & Fragilariopsis spp. (15) \\
\hline 3 & ORK & 7.21 & 70 & 30 & 0 & C. pennatum (43) \\
\hline 4 & ORK & 252.55 & 97 & 3 & 0 & C. pennatum (60) \\
\hline 5 & ORK & 98.78 & 95 & 5 & 0 & C. pennatum (70) \\
\hline 6 & ORK & 29.99 & 89 & 11 & 0 & C. pennatum (63) \\
\hline \multirow[t]{2}{*}{9} & ORK & 25.13 & 78 & 21 & 0 & C. pennatum (54) \\
\hline & Avg & 61 & 77 & 23 & 0 & \\
\hline 8 & S-SCOT & 37.76 & 51 & 30 & 18 & C. pennatum (25) \\
\hline 10 & S-SCOT & 15.80 & 5 & 44 & 51 & C. pennatum (2) \\
\hline 11 & S-SCOT & 11.20 & 27 & 40 & 33 & C. pennatum (25) \\
\hline 13 & S-SCOT & 13.68 & 27 & 33 & 40 & C. pennatum (20) \\
\hline \multirow[t]{2}{*}{14} & S-SCOT & 13.27 & 15 & 58 & 27 & C. pennatum (13) \\
\hline & Avg & 18 & 25 & 41 & 34 & \\
\hline 15 & MID-SCOT & 14.98 & 21 & 79 & 0 & C. pennatum (15) \\
\hline 16 & MID-SCOT & 22.13 & 52 & 48 & 0 & C. pennatum (47) \\
\hline 17 & MID-SCOT & 18.24 & 31 & 69 & 0 & C. pennatum (23) \\
\hline 18 & MID-SCOT & 7.23 & 18 & 82 & 0 & C. pennatum (14) \\
\hline 19 & MID-SCOT & 4.50 & 25 & 75 & 0 & C. pennatum (15) \\
\hline 20 & MID-SCOT & 6.20 & 54 & 46 & 0 & Proboscia spp. (31) \\
\hline 21 & MID-SCOT & 8.07 & 29 & 71 & 0 & C. pennatum (17) \\
\hline \multirow[t]{2}{*}{22} & MID-SCOT & 13.38 & 52 & 48 & 0 & C. pennatum (39) \\
\hline & Avg & 12 & 35 & 65 & 0 & \\
\hline 24 & SW-SG & 36.14 & 71 & 29 & 0 & P. lineola (29) \\
\hline 25 & SW-SG & 129.22 & 93 & 7 & 0 & P. lineola (40) \\
\hline 26 & SW-SG & 92.62 & 87 & 13 & 0 & P. lineola (31) \\
\hline 27 & SW-SG & 34.38 & 73 & 27 & 0 & Chaetoceros spp. (42) \\
\hline 28 & SW-SG & 63.83 & 80 & 20 & 0 & P. lineola (23) \\
\hline 29 & SW-SG & 67.93 & 81 & 19 & 0 & P. lineola (26) \\
\hline \multirow[t]{2}{*}{30} & SW-SG & 62.92 & 82 & 18 & 0 & T. antarctica (19) \\
\hline & Avg & 70 & 81 & 19 & 0 & \\
\hline 31 & NW-SG & 79.35 & 84 & 16 & 0 & T. antarctica (26) \\
\hline 32 & NW-SG & 57.89 & 71 & 29 & 0 & M. adele (21) \\
\hline 33 & NW-SG & 36.21 & 80 & 20 & 0 & T. antarctica (28) \\
\hline \multirow[t]{2}{*}{34} & NW-SG & 106.37 & 92 & 8 & 0 & T. antarctica (29) \\
\hline & $A v g$ & 70 & 82 & 18 & 0 & \\
\hline
\end{tabular}

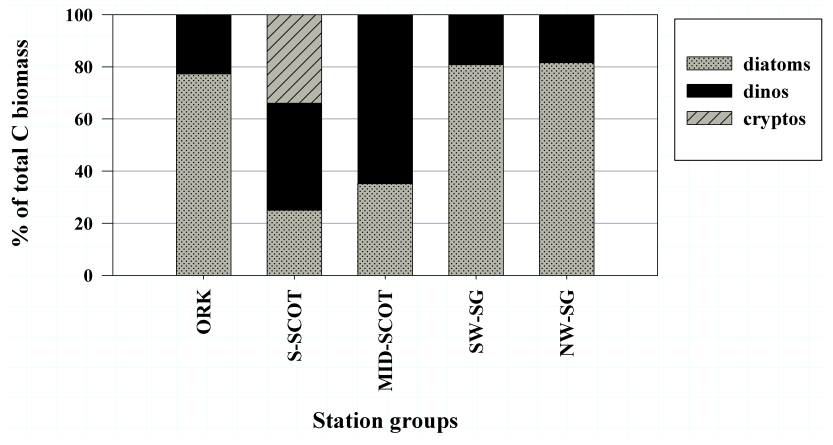

Fig. 4. Microplankton community composition in terms of carbon biomass of the station groups for the 2008 cruise.
South Georgia and only moderate to low levels of Chl $a$ were observed further south (Figs. 5 and 6). In 2008, the bloom was intense and constrained to the area of the Georgia Basin. In 2003, the bloom was less intense but spread over a wider area. The satellite images corresponded well with the pattern of Chl $a$ distribution found on both cruises and surface values were significantly higher ( $p$ values $<0.001$ ) in the NW-SG groups $\left(\sim 4-6 \mathrm{mg} \mathrm{m}^{-3}\right)$ and lower $\left(<1.9 \mathrm{mg} \mathrm{m}^{-3}\right)$ in all other station groups (Table 4). In addition, depth integrated Chl $a$ of both cruises was also significantly higher in the NW-SG groups $\left(>130 \mathrm{mg} \mathrm{m}^{-2}\right)$ than all other groups $\left(<75 \mathrm{mg} \mathrm{m}^{-2}\right)$.

On both cruises, euphotic depths were dependent on water column Chl $a$ values and were shallowest in the NWSG groups $(\sim 19$ and $32 \mathrm{~m})$ and deepest (56 and $84 \mathrm{~m}$ ) in the MID-SCOT groups with the 2 groups being significantly 


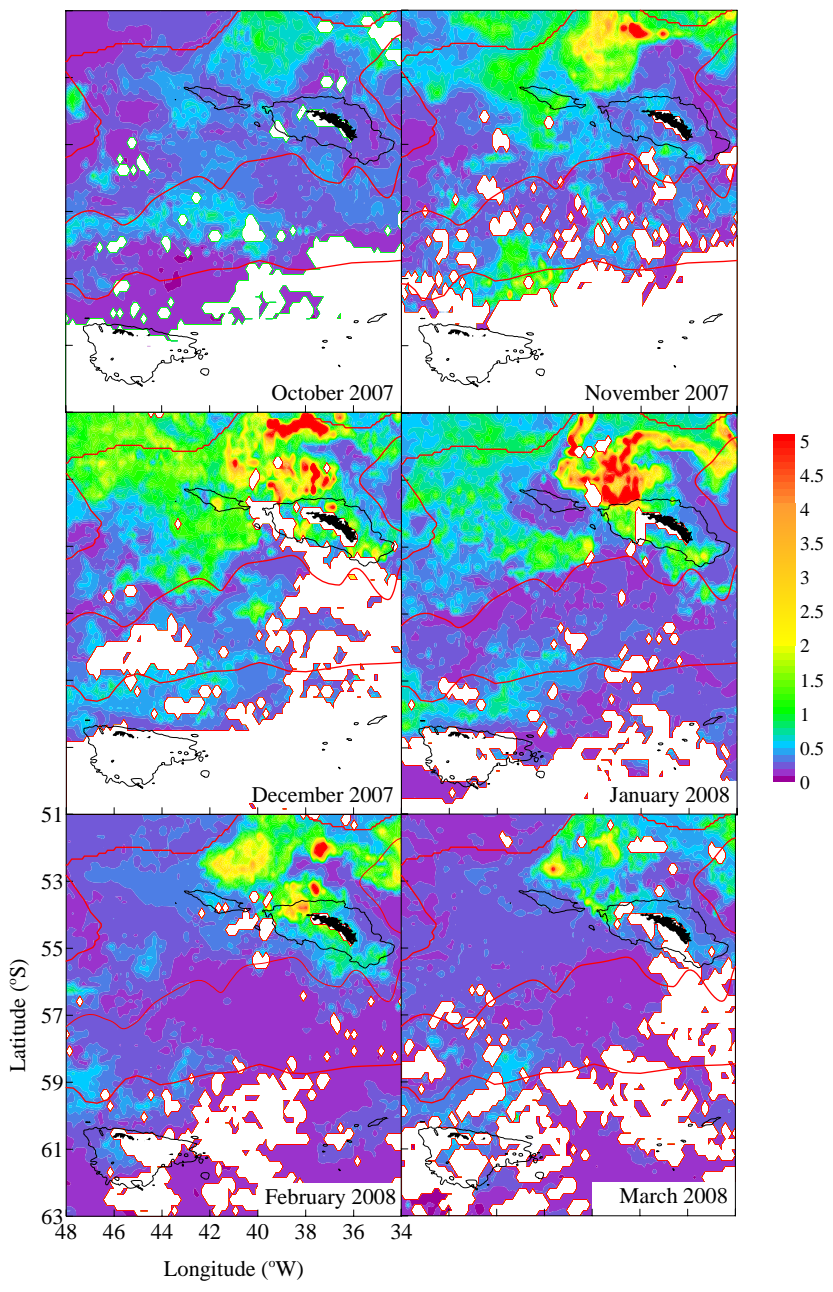

Fig. 5. Monthly composites of MODIS-Aqua Chl $a$ concentrations $\left(\mathrm{mg} \mathrm{m}^{-3}\right)$ in the Scotia Sea from October 2007 to March 2008. White areas indicate clouds and/or sea-ice. Frontal positions are marked as thin red lines.

different to each other (all $p$ values $<0.001$ ). On the 2008 cruise, UML depths were shallow in the ORK group, increased northwards, were deepest in the SW-SG group and then shoaled again in the NW-SG group (Table 4). There were significant differences in UML between groups ( $p<0.001$ ) during the 2008 cruise but not the 2003 cruise. In the more southerly station groups, euphotic depth exceeded the UML during both cruises. However, in the SW-SG and NW-SG groups, euphotic depth was close to, or shallower than the UML (Table 4).

\subsection{Macronutrient parameters across the Scotia Sea}

\subsubsection{Surface $(0-25 \mathrm{~m})$ macronutrient concentrations}

A north to south gradient across the station groups was observed in surface silicate concentration during both surveys. Lowest values were seen in the NW-SG groups $(\sim 3$

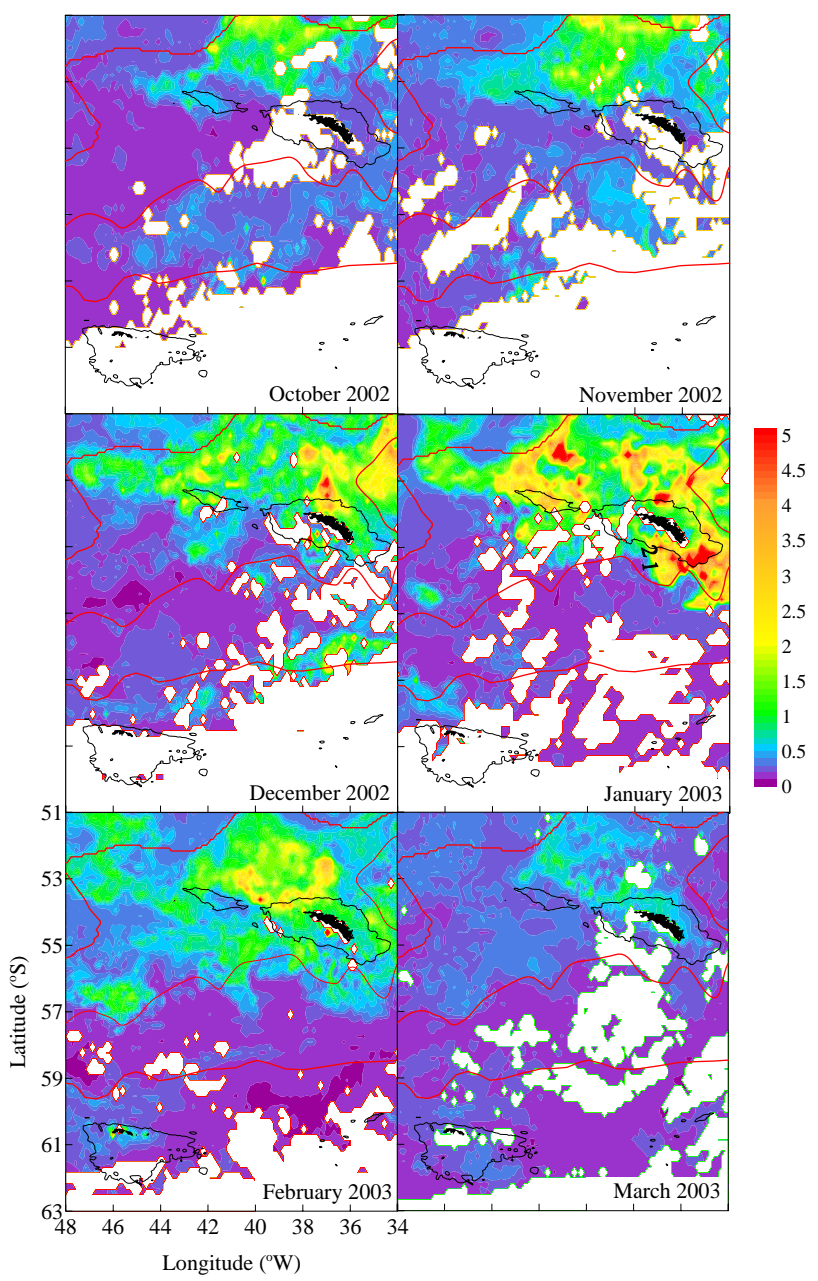

Fig. 6. Monthly composites of MODIS-Aqua Chl $a$ concentrations $\left(\mathrm{mg} \mathrm{m}^{-3}\right)$ in the Scotia Sea from October 2002 to March 2003. White areas indicate clouds and/or sea-ice. Frontal positions are marked as thin red lines.

and $7 \mathrm{mmol} \mathrm{m}^{-3}$ ) and highest values in the ORK group (>60 $\mathrm{mmol} \mathrm{m}^{-3}$; Table 5).

Surface nitrate and phosphate showed a similar latitudinal gradation on both cruises with lowest concentrations (12-16 and $0.4-1.0 \mathrm{mmol} \mathrm{m}^{-3}$, respectively) in the NW-SG group and highest ( $\sim 28$ and $1.8 \mathrm{mmol} \mathrm{m}^{-3}$, respectively) at the southerly ORK and MID-SCOT groups. The NW-SG region was also notable for high stocks of ammonium with an average $>3 \mathrm{mmol} \mathrm{m}^{-3}$ during both cruises (data not shown).

\subsubsection{Regional macronutrient deficits}

A significant latitudinal gradient $(p<0.001)$ was found for all macronutrient deficits (WW minus surface values) on both cruises (Table 5). This was especially so for silicate with a reduction in concentrations of $>33 \mathrm{mmol} \mathrm{m}^{-3}$ in the NWSG groups and $<13 \mathrm{mmol} \mathrm{m}^{-3}$ at the ORK group. Similarly, nitrate and phosphate depletions of $>12$ and $1 \mathrm{mmol} \mathrm{m}^{-3}$ 
Table 4. Station group averages and standard deviations for surface $(20 \mathrm{~m})$ and depth integrated $\mathrm{Chl} a$, euphotic depth and mixed layer depth for the 2003 and 2008 cruises.

\begin{tabular}{lrrrr}
\hline Group & $\begin{array}{r}\text { Surface } \\
\text { Chl } a\left(\mathrm{mg} \mathrm{m}^{-3}\right)\end{array}$ & $\begin{array}{r}\text { Int Chl } a \\
\left(\mathrm{mg} \mathrm{m}^{-2}\right)\end{array}$ & $\begin{array}{r}\text { Euphotic } \\
\text { depth }(\mathrm{m})\end{array}$ & $\begin{array}{r}\mathrm{UML} \\
(\mathrm{m})\end{array}$ \\
\hline $\mathbf{2 0 0 8}$ & & & & \\
ORK & $0.7(0.4)$ & $51.1(23.6)$ & $68(15)$ & $16(3)$ \\
S-SCOT & $1.7(0.6)$ & $75.4(24.2)$ & $46(16)$ & $28(8)$ \\
MID-SCOT & $0.4(0.3)$ & $22.5(4.8)$ & $84(22)$ & $43(9)$ \\
SW-GEORG & $1.5(0.8)$ & $56.8(11.6)$ & $47(14)$ & $61(7)$ \\
NW-GEORG & $3.6(1.6)$ & $134.4(43.0)$ & $32(6)$ & $46(20)$ \\
2003 & & & & \\
ORK & $0.7(0.3)$ & $33.7(12.1)$ & $44(5)$ & $19(3)$ \\
MID-SCOT & $0.3(0.2)$ & $17.4(6.8)$ & $56(10)$ & $30(14)$ \\
SW-GEORG & $1.9(1.2)$ & $60.2(27.6)$ & $35(14)$ & $30(16)$ \\
NW-GEORG & $6.3(3.1)$ & $147.1(50.6)$ & $19(5)$ & $30(14)$ \\
\hline
\end{tabular}

respectively in the NW-SG groups contrasted with values of $<6$ and $0.4 \mathrm{mmol} \mathrm{m}^{-3}$ in the ORK group. There were also significant differences $(p<0.05)$ in silcate:nitrate deficit ratios with higher values of 3.0-5.5 found in the SW-SG and MID-SCOT groups compared with elsewhere. The Nitrate:Phosphate depletion ratio showed less regional variability $(p=0.52)$. However, some of the lowest ratios were coincident with the highest ammonium concentrations (near South Georgia) and vice versa in some open-ocean regions.

\section{Discussion}

From analysis of ocean colour, satellite data, the Scotia Sea has been described as one of the most productive sectors of the Southern Ocean (Comiso et al., 1993; Arrigo et al., 1998). However, oceanographic surveys have also demonstrated the patchiness of blooms in the region, with areas of very high biomass and productivity adjacent to patches of HNLC-like water (Holm-Hansen et al., 2004b; Korb et al., 2005). Our 2008 survey provided a unique opportunity for a detailed view of summertime communities over a wide latitudinal gradient across the Scotia Sea. Our survey covered both productive and unproductive environments and crossed a number of frontal and island systems. We found five distinct microplankton communities associated with the various water masses and topographical features across the Scotia Sea. Here we examine some of the main environmental factors shaping these communities, compare them to a 2003 Southern Ocean study, and discuss the implications of community structure to carbon export.

\subsection{South Orkneys group (ORK)}

Environmental conditions in this group of stations appeared to be favourable for growth. Macronutrients were abundant with silicate, nitrate and phosphate concentrations up to 76,27 and $1.8 \mathrm{mmol} \mathrm{m}^{-3}$ in the surface waters. The water column was characterised by shallow mixed layers and favourable light conditions with euphotic depth almost 5 times that of the mixed layer. However, Chl $a$ concentrations remained low with mean surface values of $0.7 \mathrm{mg} \mathrm{m}^{-3}$ and water column integrated values of $51 \mathrm{mg} \mathrm{m}^{-2}$. Additionally, nutrient deficit ratios were low $\left(7\right.$ and $3 \mathrm{mmol} \mathrm{m}^{-3}$ for silicate and nitrate, respectively) indicating that little growth had occurred prior to our survey. Although the region was relatively ice-free at the time of sampling, 2 weeks prior to our survey it was covered with sea-ice (NSDIC sea-ice data, Fetterer et al., 2002). It is possible that at the time of our survey, phytoplankton had yet to respond to the increasing light levels of a retreating ice edge to reach bloom proportions. However, MODIS images (Fig. 5) show little evidence of a surface bloom developing during the months following our study.

Numerically, this region was composed of a mixed community of naked, heterotrophic dinoflagellates $(62 \%$ of the total) and diatoms (37\%). However, in terms of carbon biomass, diatoms were the greatest contributor, accounting for $77 \%$ of the total. Biomass was dominated by two species; the heavily silicified Fragilariopsis spp. and Corethron pennatum. The latter species was never numerically abundant, accounting for less than $8 \%$ of the total cell count but its massive size $\left(\sim 8600 \mathrm{pg} \mathrm{C}^{-1 l^{-1}}\right)$ contributed significantly to overall biomass. These diatoms were found in iron-limited regions in the vicinity of the Crozet islands (Poulton et al., 2007), South Georgia (Whitehouse et al., 2008) and the Kerguelen Islands (Armand et al., 2008). Indeed, both species have been reported as being characteristic of HNLC regions of the open Antarctic Circumpolar Curent (Smetacek et al., 2004).

Typically HNLC conditions are attributed to a lack of iron in surface waters (e.g. de Baar et al., 2005; Boyd et al., 2007). The many bathymetric features of the Scotia Sea are possible sources of iron to surface waters (Holm-Hansen 2004b; Holeton et al., 2005; Korb and Whitehouse, 2004; Korb et al., 2005), yet few direct measurements of dissolved iron concentrations exist for the region. The underlying topography of our ORK group was variable with seabed depths ranging from $\sim 300-3000 \mathrm{~m}$ and shelf-sediment interactions might be expected to contribute iron to the water column (Tyrrell et al., 2005). However, macronutrient data further suggested that the ORK group was not an iron-rich environment. In ironreplete waters of the Southern Ocean, silicate:nitrate uptake ratios are $\sim 1: 1$ and $>2: 1$ in iron-poor waters (Frank et al., 2000). In our study, silicate:nitrate deficit ratios of $\sim 2: 1$ suggest a degree of iron limitation. This may then account for the low Chl $a$ conditions of this region and the high proportion of heterotrophic dinoflagellates. During the 2003 survey, Chl $a$ concentrations were also low and the community dominated by diatoms typical of low-iron waters (Thalassionema/Fragilariopsis spp.; Smetacek et al., 2004). Again, silicate:nitrate deficit ratios were $>2: 1$, further suggesting the area was iron-poor. 
Table 5. Station group averages and standard deviations for surface $(0-25 \mathrm{~m})$ macronutrient concentrations $\left(\mathrm{mmol} \mathrm{m}^{-3}\right)$, deficits $($ winter water minus surface values) and deficit ratios for the 2003 and 2008 cruises.

\begin{tabular}{|c|c|c|c|c|c|c|c|c|}
\hline Group & $\begin{array}{l}0-25 \mathrm{~m} \\
\text { Silicate }\end{array}$ & $\begin{array}{l}0-25 \mathrm{~m} \\
\text { Nitrate }\end{array}$ & $\begin{array}{r}0-25 \mathrm{~m} \\
\text { Phosphate }\end{array}$ & $\begin{array}{r}\text { Silicate } \\
\text { deficit }\end{array}$ & $\begin{array}{r}\text { Nitrate } \\
\text { deficit }\end{array}$ & $\begin{array}{r}\text { Phosphate } \\
\text { deficit }\end{array}$ & $\begin{array}{r}\text { Silicate:Nitrate } \\
\text { deficit ratio }\end{array}$ & $\begin{array}{r}\text { Nitrate:Phosphate } \\
\text { deficit ratio }\end{array}$ \\
\hline \multicolumn{9}{|l|}{2008} \\
\hline ORK & $76.26(4.79)$ & $26.70(1.36)$ & $1.75(0.11)$ & $6.91(4.28)$ & $3.35(1.73)$ & $0.25(0.09)$ & $2.10(1.13)$ & $13.02(2.94)$ \\
\hline S-SCOT & $75.60(0.81)$ & $25.71(2.43)$ & $1.59(0.05)$ & $9.51(0.82)$ & $6.36(3.06)$ & $0.42(0.11)$ & $1.73(0.96)$ & $14.69(3.30)$ \\
\hline MID-SCOT & $56.28(16.81)$ & $23.38(0.73)$ & $1.62(0.05)$ & 16.09 (5.67) & $6.44(0.58)$ & $0.44(0.01)$ & $2.53(0.99)$ & $14.68(1.55)$ \\
\hline SW-SG & $8.33(7.42)$ & $21.63(1.89)$ & $1.45(0.19)$ & $23.83(9.50)$ & 7.79 (2.49) & $0.57(0.16)$ & $3.01(0.66)$ & $13.64(0.42)$ \\
\hline NW-SG & $6.95(9.83)$ & $15.99(2.92)$ & $1.04(0.13)$ & $35.58(15.65)$ & $12.64(0.66)$ & $0.98(0.06)$ & $2.79(1.09)$ & $12.94(0.06)$ \\
\hline \multicolumn{9}{|l|}{2003} \\
\hline ORK & $60.27(0.72)$ & $26.92(3.07)$ & $1.76(0.19)$ & $12.50(4.19)$ & $5.71(2.11)$ & $0.40(0.20)$ & $2.26(0.68)$ & $15.73(4.34)$ \\
\hline MID-SCOT & 51.35 (12.69) & $29.01(0.57)$ & $1.86(0.05)$ & $20.99(10.45)$ & $3.86(0.88)$ & $0.30(0.07)$ & $5.49(2.99)$ & 13.14 (1.49) \\
\hline SW-SG & $12.58(13.20)$ & $24.86(3.03)$ & $1.46(0.19)$ & $27.29(5.24)$ & $7.49(2.21)$ & $0.66(0.17)$ & $3.80(0.72)$ & $11.31(0.75)$ \\
\hline NW-SG & $2.54(0.60)$ & $11.99(1.89)$ & $0.44(0.07)$ & $33.75(1.72)$ & $17.39(1.25)$ & $1.62(0.08)$ & $1.95(0.22)$ & $10.79(1.10)$ \\
\hline
\end{tabular}

\subsection{Southern Scotia Sea (S-SCOT)}

The key characteristic of the S-SCOT region was the abundance of cryptophytes, which were virtually absent elsewhere in our Scotia Sea survey. Here, cryptophytes accounted for over half of the total phytoplankton count and surface $\mathrm{Chl} a$ concentrations were elevated to $1.7 \mathrm{mg} \mathrm{m}^{-3}$. Over the South Scotia Ridge, in a region some $5^{\circ} \mathrm{W}$ of our transect, a high biomass of cryptophytes was found along the retreating ice edge (Jacques and Panouse, 1991; Buma et al., 1992). Our S-SCOT group was located just north of the South Scotia Ridge with stations largely situated over deep water from $\sim 1000$ to $4000 \mathrm{~m}$ depth and part of this region was covered with sea ice in November 2007 which had retreated to the south by December (Fig. 5). Garibotti et al. (2005) reported that cryptophyte assemblages in the seasonal ice zone of the Antarctic Peninsula were an annual occurrence. At present, we cannot conclude if this is the case in our S-SCOT region. Taxonomic resolution of cell counts for the 2003 survey, was coarse and it is possible that very small cryptophytes $(<10 \mu \mathrm{m})$ were present but not seen in our cell counts. Given the occurrence of this group in the survey of Jacques and Panouse (1991), 20 years prior to our 2008 cruise, and an annually retreating ice edge in the area, a cryptophyte community may be a regular occurrence in this region.

Garibotti et al. (2005) reported that massive cryptophyte blooms, near the Antarctic Peninsula, constituted a secondary stage of seasonal phytoplankton succession, following on from a diatom bloom. In our study, a similar pattern was observed with the S-SCOT community almost devoid of diatoms. However, macronutrient concentrations suggest that diatom blooms had not occurred prior to our survey. There was little depletion of silicate $\left(9.5 \mathrm{mmol} \mathrm{m}^{-3}\right)$ from the water column but this region did show a modest depletion in nitrate $\left(\sim 6 \mathrm{mmol} \mathrm{m}^{-3}\right)$, presumably due to the cryp- tophyte bloom. Cell counts from the 2003 survey at stations 5.4 and 5.5 (Table 2) suggest that diatoms were prevalent in the area $(\sim 50 \%$ of total), although whether or not this preceded a cryptophyte bloom in unknown.

\subsection{Central Scotia Sea (MID-SCOT)}

During the 2008 survey, this region of the Scotia Sea was characterised, almost exclusively, by the presence of smallmedium sized, naked dinoflagellates, accounting for $96 \%$ of the cell count at all stations. Despite apparently favourable environmental conditions for growth (shallow MLD, deep euphotic depth, abundant macronutrients), Chl $a$ remained low $\left(0.4 \mathrm{mg} \mathrm{m}^{-3}\right)$ and diatoms made up only $4 \%$ of the community. MODIS images (Fig. 5) show little evidence of a bloom developing in the months following our study. In terms of biomass, diatoms were important with the numerically rare, but large, Corethron pennatum contributing $35 \%$ of the total.

The low abundance of diatoms in 2008, contrasts with 2003 where diatoms accounted for $47 \%$ of the total count in the MID-SCOT group. Diatoms were mainly composed of the heavily silicified Fragilariopsis kerguelensis (up to 22\% of the total count). However, Chl $a$ levels remained low with surface levels at $0.4 \mathrm{mg} \mathrm{m}^{-3}$ and small, naked dinoflagellates accounted for the rest of the microplankton community $(53 \%)$.

As previously noted, Fragilariopsis kerguelensis, together with Corethron pennatum, are typical of HNLC regions of the open Antarctic Circumpolar Current (Smetacek et al., 2004). Naked dinoflagellates are obligate heterotrophs and major grazers of the microbial foodwebs characterising HNLC environments. Thus the repeat occurrence of HNLC type communities (F. kerguelensis, $C$. pennatum and small/naked, heterotrophic dinoflagellates) and silicate:nitrate deficit ratios up to 5.5:1 suggests that this region 
remains a HNLC area year after year. However, a cursory examination of January MODIS images, from 2002 to 2008, over the region of 56 to $60^{\circ} \mathrm{S}$ and 45 to $42^{\circ} \mathrm{W}$ indicates that this region is not always characterised by HNLC conditions (data not shown). January MODIS Chl $a$ values, averaged over the area, were 2-3 times lower during our cruise surveys $\left(0.22-0.34 \mathrm{mg} \mathrm{m}^{-3}\right)$ than the summers from 2004 to $2007\left(0.89\right.$ to $\left.1.04 \mathrm{mg} \mathrm{m}^{-3}\right)$. Why the region should exhibit HNLC characteristics in some years and not in others is at present unclear but is undoubtedly a result of the complex interaction of current flow with the complicated bathymetry of the Scotia Sea.

\subsection{South-west of South Georgia (SW-SG)}

Towards the land mass of South Georgia, there was a distinct shift to a diatom dominated community. In the SWSG group, although naked dinoflagellates were still present in significant numbers ( $38 \%$ of the total), diatoms made up the majority of the cell counts (62\%). In addition, the heavily silicified species observed further south were replaced by less silicified forms such as Pseudonitzschia lineola and Chaetoceros spp. These diatoms dominated the microplankton community in terms of both cell abundance and biomass with a further contribution to biomass seen with Thalassiothrix antarctica close to South Georgia (station D30). The 2003 survey showed an even greater contribution from diatoms (87\% of total) with a prevalence of Chaetoceros spp.

During both surveys, moderate surface blooms were observed with $\mathrm{Chl} a$ levels $>1.5 \mathrm{mg} \mathrm{m}^{-3}$. In addition, water column integrated $\mathrm{Chl} a$ values were also moderate at $\sim 58 \mathrm{mg} \mathrm{m}^{-2}$. Despite surface blooms, the water column did not appear favourable for diatom growth. Silicate was seriously depleted in the region during both surveys, with deficits $\sim 26 \mathrm{mmol} \mathrm{m}^{-3}$, highlighting phytoplankton growth prior to our study. In addition, silicate:nitrate deficit ratios were high (>3:1), suggesting an iron-deficient water column. Examination of MODIS images for the 2008 survey shows that the bloom in the SW-SG region was at its peak in December 2007 (Fig. 5). By the time we had reached the region near the end of January 2008, the bloom was beginning to decline and by February it had virtually disappeared. Weak circulation around the island of Crozet ensures that macronutrients and iron are not resupplied to phytoplankton blooms during the summer (Pollard et al., 2009). As a result, blooms die back around January (Venables et al., 2007). Our SW-SG region is upstream of South Georgia in terms of water flow around the island. It is possible that a situation similar to Crozet arises here with winter nutrient accumulation of surface waters (and light limitation of phytoplankton growth) followed by depletion during rapid growth in December. A lack of resupply could then lead to the demise of the bloom.

www.biogeosciences.net/7/343/2010/

\subsection{North-west of South Georgia (NW-SG)}

The annually occurring mega blooms of this region are well documented and are typically composed of diatoms (e.g. Atkinson et al., 2001; Korb et al., 2008). During our 2003 and 2008 surveys, diatoms were the main component of the microplankton community. Small celled Melosira adele (42 pg C cell-1) dominated cell counts and the large Thalassiothrix antarctica (1321 pg C cell-1) contributed to biomass in 2008. In 2003, Eucampia antarctica was the major diatom contributor.

During both surveys, mixed layer depths exceeded euphotic depths, and silicate deficits were high $\left(\sim 35 \mathrm{mmol} \mathrm{m}^{-3}\right)$. However, dense blooms could be seen in the region until March when Chl $a$ levels began to decline, most likely due to the onset of light limitation. Silicate:nitrate ratios were variable between the 2 cruises (1.9 and 2.8:1) indicating an iron-replete and iron-poor environments. In contrast to the SW-SG region, the longevity of the NW-SG bloom is likely to follow the scenario observed for Kerguelen whereby surface waters are continually resupplied with macronutrients and iron from surrounding waters and from below (Blain et al., 2007). Indeed, water flow through the NW-SG region is complicated and several physical processes including shelf-sediment interactions, upwelling at the southwest shelf, land run-off and eddy shedding from the Polar Front and Southern Antarctic Circumpolar Current Front could provide a steady supply of nutrients to diatoms through the growing season (Whitehouse et al., 1996, 2000, 2008; Korb et al., 2008).

\subsection{Implications to biogeochemistry in the Scotia Sea}

The structure of microplankton communities in the Southern Ocean, is a key process influencing the biological carbon pump (Boyd and Trull, 2007; De La Rocha and Passow, 2007). In particular, the structure of diatom communities can determine whether silicon or carbon is exported to depth. According to Smetacek (2004), productive, ironrich waters will typically support diatom blooms containing large to medium sized, but weakly silicified, forms such as Chaetoceros spp. In contrast, unproductive, iron-poor waters are composed mainly of a microbial food web but also lead to the accumulation of heavily silicified diatoms such as Fragilariopsis kerguelensis. These differences in diatom communities are reflected in the underlying sediments with preferential export of silicon in low production areas and export of carbon in high production areas (Treguer and Jacques, 2002; de Baar et al., 2005, Boyd et al., 2007).

Our 2008 Scotia Sea survey covered areas of both high and low productivity and showed 5 distinct phytoplankton communities. Although little detailed information exists on diatom distribution in the underlying sediments of the Scotia Sea, Fragilariopsis kerguelensis is generally reported to be the most dominant species found in surface sediments of the 
Southern Ocean (Armand et al., 2005; Crosta et al., 2005; Cortese and Gersonde, 2008). Here we examine productivity (Chl $a$, biomass), community composition, together with silicate:nitrate deficit ratios (as indicators of iron stress) to propose the following view of biogeochemical dynamics across the Scotia Sea:

- ORK region-despite the proximity to the South Scotia Ridge, this region is characteristic of a microbial food web with low Chl $a$ levels and an abundance of heterotrophic dinoflagellates. Accumulation of heavily silicified diatoms (which have escaped microzooplankton grazing pressure due to their heavy armour of silica) and high silicate:nitrate deficit ratios suggests that biogenic opal is preferentially exported to depth. This agrees with the maps of Cortese and Gersonde (2007) showing high export of biogenic silica from Fragilariopsis kerguelensis.

- S-SCOT - this region was fairly productive due to the high abundance of cryptophytes. However, cryptophytes are unlikely to be exported to depth but likely recycled within the upper ocean as part of a microbial food web (supported by the abundance of hetetrotrophic dinoflagellates). Diatoms were rare except for a few heavily armoured species and it is likely that little biogenic silica or carbon are exported to depth. Maps of Cortese and Gersonde (2007) support a reduction of biogenic silica export from Fragilariopsis kerguelensis in this region.

- MID-SCOT - low production coupled with the near total dominance of heterotrophic dinoflagellates suggest that little biogenic silica or carbon would be exported from this region.

- SW-SG - our results suggest that the diatom bloom at this productive site was in decline possibly due to iron exhaustion (high silicate:nitrate ratios). However, given the weakly silicified diatoms dominating this bloom, it is likely that carbon could be exported to depth.

- NW-SG - this is a highly productive site with blooms lasting for many months and supporting a wide variety of diatoms, including many large species. Likely to be a site of high biogenic silica and carbon export.

Thus for the Scotia Sea we propose biogenic silica is preferentially exported to depth in waters south of the SACCF. In waters to the north of the SACCF and that are in the vicinity of the island of South Georgia, carbon is preferentially exported to depth. This simplistic view of export in the Scotia Sea has not taken into consideration the myriad of interactions between predator/prey at microbial and metazooplankton levels which will further influence the degree of carbon and biogenic export. However, our approach illustrates the degree of variability in important components of the export process: productivity varied by almost 10 times, and community composition fluctuated between microbial foodwebs to diatom blooms, over a distance of $\sim 700 \mathrm{~km}$.

Acknowledgements. This work was a component of the British Antarctic Survey's DISCOVERY-2010 programme. Thanks to A. Fleming at BAS for providing sea-ice edge data courtesy of NSIDC Sea Ice Index. We are grateful to NASA's Ocean Colour Web site for provision of MODIS data. A special thanks to all the crew and scientists involved in the James Clark Ross cruises JR82 and JR177.

Edited by: E. Marañón

\section{References}

Archer, S. D., Leakey, R. J. G., Burkill, P. H., and Sleigh, M. A.: Microbial dynamics in coastal waters of East Antarctica: Herbivory by heterotrophic dinoflagellates, Mar. Ecol.-Prog. Ser., 139(1-3), 239-255, 1996.

Armand, L. K., Crosta, X., Romero, O., and Pichon, J. J.: The biogeography of major diatom taxa in Southern Ocean sediments: 1. Sea ice related species, Palaeogeogr. Palaeocl., 223(1-2), 93126, 2005.

Armand, L. K., Cornet-Barthaux, V., Mosseri, J., and Queguiner, B.: Late summer diatom biomass and community structure on and around the naturally iron-fertilised Kerguelen Plateau in the Southern Ocean, Deep-Sea Res. II, 55(5-7), 653-676, 2008.

Arrigo, K. R., Worthen, D., Schnell, A., and Lizotte, M. P.: Primary production in Southern Ocean waters, J. Geophys. Res.-Oceans, 103(C8), 15587-15600, 1998.

Atkinson, A., Whitehouse, M. J., Priddle, J., Cripps, G. C., Ward, P., and Brandon, M. A.: South Georgia, Antarctica: a productive, cold water, pelagic ecosystem, Mar. Ecol.-Prog. Ser., 216, 279308, 2001.

Blain, S., Queguiner, B., Armand, L., Belviso, S., Bombled, B., Bopp, L., Bowie, A., Brunet, C., Brussaard, C., Carlotti, F., Christaki, U., Corbiere, A., Durand, I., Ebersbach, F., Fuda, J. L., Garcia, N., Gerringa, L., Griffiths, B., Guigue, C., Guillerm, C., Jacquet, S., Jeandel, C., Laan, P., Lefevre, D., Lo Monaco, C., Malits, A., Mosseri, J., Obernosterer, I., Park, Y. H., Picheral, M., Pondaven, P., Remenyi, T., Sandroni, V., Sarthou, G., Savoye, N., Scouarnec, L., Souhaut, M., Thuiller, D., Timmermans, K., Trull, T., Uitz, J., van Beek, P., Veldhuis, M., Vincent, D., Viollier, E., Vong, L., and Wagener, T.: Effect of natural iron fertilization on carbon sequestration in the Southern Ocean, Nature, 446(7139), 1070-1074, 2007.

Boyd, P. W. and Newton, P. P.: Does planktonic community structure determine downward particulate organic carbon flux in different oceanic provinces?, Deep-Sea Res. II, 46(1), 63-91, 1999.

Boyd, P. W. and Trull, T. W.: Understanding the export of biogenic particles in oceanic waters: Is there consensus?, Prog. Oceanogr., 72(4), 276-312, 2007.

Boyd, P. W., Jickells, T., Law, C. S., Blain, S., Boyle, E. A., Buesseler, K. O., Coale, K. H., Cullen, J. J., de Baar, H. J. W., Follows, M., Harvey, M., Lancelot, C., Levasseur, M., Owens, N. P. J., Pollard, R., Rivkin, R. B., Sarmiento, J., Schoemann, V., Smetacek, V., Takeda, S., Tsuda, A., Turner, S., and Watson, A. 
J.: Mesoscale iron enrichment experiments 1993-2005: Synthesis and future directions, Science, 315(5812), 612-617, 2007.

Boyd, P. W.: Implications of large-scale iron fertilization of the oceans - Introduction and synthesis, Mar. Ecol.-Prog. Ser., 364, 213-218, 2008.

Buma, A. G. J., Gieskes, W. W. C., and Thomsen, H. A.: Abundance of Cryptophyceae and Chlorophyll B-Containing Organisms in the Weddell-Scotia Confluence Area in the Spring of 1988, Polar Biol., 12(1), 43-52, 1992.

Comiso, J. C., McClain, C. R., Sullivan, C. W., Ryan, J. P., and Leonard, C. L.: Coastal Zone Color Scanner Pigment Concentrations in the Southern-Ocean and Relationships to Geophysical Surface- Features, J. Geophys. Res.-Oceans, 98(C2), 2419-2451, 1993.

Cortese, G. and Gersonde, R.: Morphometric variability in the diatom Fragilariopsis kerguelensis: Implications for Southern Ocean paleoceanography, Earth Planet. Sci. Lett., 257(3-4), 526-544, 2007.

Cortese, G. and Gersonde, R.: Plio/Pleistocene changes in the main biogenic silica carrier in the Southern Ocean, Atlantic Sector, Mar. Geol., 252(3-4), 100-110, 2008.

Crosta, X., Romero, O., Armand, L. K., and Pichon, J. J.: The biogeography of major diatom taxa in Southern Ocean sediments: 2. Open ocean related species, Palaeogeogr. Palaeocl., 223(1-2), 66-92, 2005.

de Baar, H. J. W., Boyd, P. W., Coale, K. H., Landry, M. R., Tsuda, A., Assmy, P., Bakker, D. C. E., Bozec, Y., Barber, R. T., Brzezinski, M. A., Buesseler, K. O., Boye, M., Croot, P. L., Gervais, F., Gorbunov, M. Y., Harrison, P. J., Hiscock, W. T., Laan, P., Lancelot, C., Law, C. S., Levasseur, M., Marchetti, A., Millero, F. J., Nishioka, J., Nojiri, Y., van Oijen, T., Riebesell, U., Rijkenberg, M. J. A., Saito, H., Takeda, S., Timmermans, K. R., Veldhuis, M. J. W., Waite, A. M., and Wong, C. S.: Synthesis of iron fertilization experiments: From the iron age in the age of enlightenment, J. Geophys. Res.-Oceans, 110(C9) CO9S16, doi:10.1029/2004JCOO2601, 2005.

De La Rocha, C. L. and Passow, U.: Factors influencing the sinking of POC and the efficiency of the biological carbon pump, DeepSea Res. II, 54(5-7), 639-658, 2007.

Fetterer, F., Knowles, K., Meier, W., and Savoie, M.: Sea Ice Index, Boulder, CO: National Snow and Ice Data Center, Digital media (updated 2009), 2002.

Field, J. G., Clarke, K. R., and Warwick, R. M.: A practical strategy for analysing multispecies distribution patterns, Mar. Ecol. Prog. Ser., 8, 37-52, 1982.

Franck, V. M., Brzezinski, M. A., Coale, K. H., and Nelson, D. M.: Iron and silicic acid concentrations regulate Si uptake north and south of the Polar Frontal Zone in the Pacific Sector of the Southern Ocean, Deep-Sea Res. II, 47(15-16), 3315-3338, 2000.

Garibotti, I. A., Vernet, M., Ferrario, M. E.: Annually recurrent phytoplanktonic assemblages during summer in the seasonal ice zone west of the Antarctic Peninsula (Southern Ocean), DeepSea Res. I, 52(10), 1823-1841, 2005.

Hasle, G.: The inverted microscope method, in: Phytoplankton manual, edited by: Sournia, A., UNESCO, Paris, 1978.

Holeton, C. L., Nedelec, F., Sanders, R., Brown, L., Moore, C. M., Stevens, D. P., Heywood, K. J., Statham, P. J., and Lucas, C. H.: Physiological state of phytoplankton communities in the Southwest Atlantic sector of the Southern Ocean, as measured by fast repetition rate fluorometry, Polar Biol., 29(1), 44-52, 2005.

Holm-Hansen, O., Amos, A. F., and Hewes, C. D.: Reliability of estimating chlorophyll a concentrations in Antarctic waters by measurement of in situ chlorophyll a fluorescence, Mar. Ecol.Prog. Ser., 196, 103-110, 2000.

Holm-Hansen, O., Kahru, M., Hewes, C. D., Kawaguchi, S., Kameda, T., Sushin, V. A., Krasovski, I., Priddle, J., Korb, R., Hewitt, R. P., and Mitchell, B. G.: Temporal and spatial distribution of chlorophyll-a in surface waters of the Scotia Sea as determined by both shipboard measurements and satellite data, Deep-Sea Res. II, 51(12-13), 1323-1331, 2004a.

Holm-Hansen, O., Naganobu, M., Kawaguchi, S., Kameda, T., Krasovski, I., Tchernyshkov, P., Priddle, J., Korb, R., Brandon, M., Demer, D., Hewitt, R. P., Kahru, M., and Hewes, C. D.: Factors influencing the distribution, biomass, and productivity of phytoplankton in the Scotia Sea and adjoining waters, Deep-Sea Res. II, 51(12-13), 1333-1350, 2004b.

Jacques, G. and Panouse, M.: Biomass and Composition of Size Fractionated Phytoplankton in the Weddell-Scotia Confluence Area, Polar Biol., 11(5), 315-328, 1991.

Jennings Jr., J. C., Gordon, L. I., and Nelson, D. M.: Nutrient depletion indicates high primary productivity in the Weddell Sea, Nature, 309, 51-54, 1984.

Kirk, J. T. O.: Light and photosynthesis in Aquatic Ecosytems, Cambridge University Press, Cambridge, 1994.

Korb, R. E. and Whitehouse, M.: Contrasting primary production regimes around South Georgia, Southern Ocean: large blooms versus high nutrient, low chlorophyll waters, Deep-Sea Res. I, 51 5), 721-738, 2004.

Korb, R. E., Whitehouse, M. J., and Ward, P.: SeaWiFS in the southern ocean: spatial and temporal variability in phytoplankton biomass around South Georgia, Deep-Sea Res. II, 51(1-3), 99-116, 2004.

Korb, R. E., Whitehouse, M. J., Thorpe, S. E., and Gordon, M.: Primary production across the Scotia Sea in relation to the physicochemical environment, J/ Marine Syst., 57(3-4), 231-249, 2005.

Korb, R. E., Whitehouse, M. J., Atkinson, A., and Thorpe, S. E.: Magnitude and maintenance of the phytoplankton bloom at South Georgia: a naturally iron-replete environment, Mar. Ecol.Prog. Ser., 368, 75-91, 2008.

Meredith, M. P., Brandon, M. A., Murphy, E. J., Trathan, P. N., Thorpe, S. E., Bone, D. G., Chernyshkov, P. P., and Sushin, V. A.: Variability of hydrographic conditions to the east and northwest of South Georgia, 1996-2001, J. Marine Syst., 53(1-4), 143167, 2005.

Pollard, R., Sanders, R., Lucas, M., and Statham, P.: The crozet natural iron bloom and EXport experiment (CROZEX), DeepSea Res. II, 54(18-20), 1905-1914, 2007.

Pollard, R. T., Salter, I., Sanders, R. J., Lucas, M. I., Moore, C. M., Mills, R. A., Statham, P. J., Allen, J. T., Baker, A. R., Bakker, D. C. E., Charette, M. A., Fielding, S., Fones, G. R., French, M., Hickman, A. E., Holland, R. J., Hughes, J. A., Jickells, T. D., Lampitt, R. S., Morris, P. J., Nedelec, F. H., Nielsdottir, M., Planquette, H., Popova, E. E., Poulton, A. J., Read, J. F., Seeyave, S., Smith, T., Stinchcombe, M., Taylor, S., Thomalla, S., Venables, H. J., Williamson, R., and Zubkov, M. V.: Southern Ocean deep-water carbon export enhanced by natural iron fertilization, Nature, 457(7229), 577-580, 2009.

Poulton, A. J., Moore, C. M., Seeyave, S., Lucas, M. I., Fielding, 
S., and Ward, P.: Phytoplankton community composition around the Crozet Plateau, with emphasis on diatoms and Phaeocystis, Deep-Sea Res. II, 54(18-20), 2085-2105, 2007.

Priddle, J. and Fryxel, G.: Handbook of the common plankton diatoms of the Southern Ocean: centrales except the genus Thalassiosira, British Antarctic Survey, NERC, Cambridge, 158 pp., 1985.

Rubin, S. I., Takahashi, T., Chipman, D. W., and Goddard, J. G.: Primary productivity and nutrient utilization ratios in the Pacific sector of the Southern Ocean based on seasonal changes in seawater chemistry, Deep-Sea Res. I, 45, 1211-1234, 1998.

Schlitzer, R.: Carbon export fluxes in the Southern Ocean: results from inverse modeling and comparison with satellite-based estimates, Deep-Sea Res. II, 49(9-10), 1623-1644, 2002.

Schultes, S., Verity, P. G., Bathmann, U.: Copepod grazing during an iron-induced diatom bloom in the Antarctic Circumpolar Current (EisenEx):I. Feeding patterns and grazing impact on prey populations, J. Exp. Mar. Biol. Ecol., 338, 16-34, 2006.

Scott, F. J. and Marchant, J.: Antarctic Marine Protists, Australian Biological Resources Study and Australian Antarctic Division, 550 pp., 2005.

Smetacek, V., Assmy, P., and Henjes, J.: The role of grazing in structuring Southern Ocean pelagic ecosystems and biogeochemical cycles, Antarctic Sci., 16(4), 541-558, 2004.

Tomas, C. R.: Identifying Marine Phytoplankton, Academic Press, New York, 858 pp., 1997.
Treguer, P. and Jacques, G.: Dynamics of Nutrients and Phytoplankton, and Fluxes of Carbon, Nitrogen and Silicon in the Antarctic Ocean, Polar Biol., 12(2), 149-162, 1992.

Tyrrell, T., Merico, A., Waniek, J. J., Wong, C. S., Metzl, N., and Whitney, F.: Effect of seafloor depth on phytoplankton blooms in high-nitrate, low-chlorophyll (HNLC) regions, J. Geophys. Res.Biogeosci., 110(G2) GO2007, 2005.

Venables, H. J., Pollard, R. T., and Popova, E. E.: Physical conditions controlling the development of a regular phytoplankton bloom north of the Crozet Plateau, Southern Ocean, Deep-Sea Res. II, 54(18-20), 1949-1965, 2007.

Whitehouse, M. J.: Automated seawater nutrient chemistry, British Antarctic Survey, Cambridge, 14 pp., 1997.

Whitehouse, M. J., Priddle, J., and Symon, C.: Seasonal and annual change in seawater temperature, salinity, nutrient and chlorophyll a distributions around South Georgia, South Atlantic, Deep-Sea Res. I, 43(4), 425-443, 1996.

Whitehouse, M. J., Priddle, J., and Brandon, M. A.: Chlorophyll/nutrient characteristics in the water masses to the north of South Georgia, Southern Ocean, Polar Biol., 23(6), 373-382, 2000.

Whitehouse, M. J., Korb, R. E., Atkinson, A., Thorpe, S. E., and Gordon, M.: Formation, transport and decay of an intense phytoplankton bloom within the High-Nutrient Low-Chlorophyll belt of the Southern Ocean, J. Marine Syst., 70(1-2), 150-167, 2008. 